\section{EREM 76/3}

Journal of Environmental Research Engineering and Management

Vol. 76 / No. 3 / 2020

pp. 6-15

DOI 10.5755/j01.erem.76.3.27338
Wind Power Integration Peculiarities in the Electricity System of the Baltic States

\begin{tabular}{|l|l}
\hline Received 2020/06 & Accepted after revision 2020/08 \\
\hline
\end{tabular}

\title{
Wind Power Integration Peculiarities in the Electricity System of the Baltic States
}

\section{Giedrius Gecevičius*}

Kaunas University of Applied Sciences, Pramonès pr. 20, Kaunas, LT-50468, Lithuania

\section{Mantas Marčiukaitis}

Lithuanian Energy Institute, Breslaujos 3, Kaunas, LT-44403, Lithuania

*Corresponding author: giedrius.gecevicius@go.kauko.lt

Analysis of wind power utilization efficiency around the world and Europe has revealed the gap between feasible and factual power generation. The paper presents an investigation of wind power generation dynamics, penetration levels into the electricity system, and dependence of capacity factors on the hub height and the rotor diameter of wind turbines in the Baltic States. These factors are the main for the evaluation of wind power utilization efficiency. Wind power penetration levels show that possibilities of the energy system to accept more wind power installations in the Baltic States are far away from its limit. Besides, dependence of high wind turbines capacity factors' on the hub height and the rotor diameter in the range of 20-120 m was revealed.

Keywords: capacity factor, penetration, wind power.

\section{Introduction}

In order to implement the European Union's energy policy targets to mitigate climate change and increase energy security, the Baltic States pay more attention to renewable energy sources, especially wind energy (Table 1).
However, such an electricity generation technique causes different problems with the reliability of the energy system due to the necessary constant balance between energy production and consumption (Hu et al., 2017). For example, if all installed capacity was used for the 
Table 1. Wind power actual installations and plans in the Baltic States

\begin{tabular}{l|c|c}
\hline \multicolumn{1}{|c|}{ Country } & $\begin{array}{c}2019 \text { actual } \\
\text { installations, MW }\end{array}$ & 2030 plans, MW \\
\hline Lithuania & 548 & 1322 \\
\hline Latvia & 66 & 800 \\
\hline Estonia & 320 & 1200 \\
\hline
\end{tabular}

power production in 2012 wind power could provide $14.7 \%$ of the world's electricity consumption; however, in 2013, about 212 GWh of electricity produced using existing wind power capacity was not transferred to the network (Li et al., 2015). This is due to low capacity factors of installed wind turbines and is apparent from countries such as China, the US, Germany and Spain, where power generation capacity lags behind the installed capacity growth rate (Benatia et al., 2013; Voumvoulakis et al., 2012). In order to ensure reliable and safe operation of the electricity system and to use wind power as efficiently as possible, reliable wind power indicators and characteristics are necessary.

The capacity factor is an important indicator of wind power efficiency. The development of wind power plants has enabled the identification of actual wind power capacity factors and has revealed that capacity factor ratios were generally lower than initially assumed (Benatia et al., 2013). Depending on the power capacity, the wind power capacity factor values range from 20 to 40\% (Chang et al., 2014).

As the average capacity factor defines the generation of electricity and the return on investment, an undefined true value of the capacity factor has a negative impact on investors. For example, in the EU-15, the average actual capacity factor for the period 2003-2007 was $21 \%$, but the estimated capacity factor was $35 \%$ (Benatia et al., 2013). For this reason, the average cost of wind energy production increased by $66 \%$. Besides, the operation of the wind power system is most affected by the capacity factor values (Bortolini et al., 2014), and the study of its dependence on various factors is important in order to use wind power as efficiently as possible.

The design of wind power plants influences the capacity factor and the suitability for wind conditions.
Recently, wind turbine constructions have been developed towards higher power, increasing tower height and blade length (Dai et al., 2016; Hu et al., 2017; Mondal et al., 2010). With lower wind speeds, rotors with high masts and long blades, depending on the size of the generator and sometimes higher capacity, are more suitable than high-speed structures (Lacerda et al., 2016). However, the height increase of the hub and the length of the blades have limited values that affect the value of the capacity factor. It is important to estimate these limitations in order to avoid additional costs for expensive wind turbine tower and blades.

The location influences the capacity factor due to wind speed. Electricity production is calculated on the basis of kinetic energy (derived from weather conditions), but also on transmission factors such as penetration rate, correlation with peak demand, proximity to end-users, and variability and predictability of annual and seasonal wind speeds (Boccard, 2009).

The paper presents evaluation of the dynamics of wind turbine utilization capacity, identifies wind turbine capacity factors that determine their efficiency, and analyses wind power penetration levels in the Baltic States. Finally, opportunities aimed at reducing the gap between electricity generation capacity and production are identified and presented.

\section{Methodology}

The location of wind turbines in the Baltic States is presented in Fig. 1. Most wind turbines are situated on the coastline of the Baltic Sea. The 4-6 m/s average wind speed is prevailing.

In order to compare the effectiveness and similarities between wind power parameters in the Baltic States, data from national power transmission system operators (TSO) were analysed (Litgrid from Lithuania, Augstsprieguma tīkls from Latvia, and Elering from Estonia) (Table 2).

Three indicators for different penetration levels were analysed. Gross demand penetration (GDP) can be defined as the ratio of average wind power capacity and average power load capacity on annual basis (Lacerda et al., 2016) (Eq. 1): 


$$
G D P=\frac{P_{\text {Average WT }}}{P_{\text {Average load }}}
$$

where: $P_{\text {Average } W T}$ - average annual wind power capacity $(\mathrm{MW}) ; P_{\text {Average load }}$ - average annual power load (MW). Another indicator is wind capacity penetrations (WCP), which describes the ratio of installed wind power capacity and peak load (Lacerda et al., 2016) (Eq. 2):

$$
W C P=\frac{P_{\text {Installed capacity } W T}}{P_{\text {Peak load }}}
$$

where: $P_{\text {Installed capacity WT }}$ - installed wind power capacity (MW); $P_{\text {Peak load }}$ - peak load of power system (MW).

The maximum share of wind power (MSP) describes the ratio of maximum generated wind power and minimum load (Lacerda et al., 2016) (Eq. 3):

$$
M S P=\frac{P_{\text {Maximum WT }}}{P_{\text {Minimum load }}}
$$

where: $P_{\text {Maximum } w T}-$ maximum generated wind power (MW); $P_{\text {Minimum load }}-$ minimum load of power system (MW).
Fig. 1. Wind turbines in the Baltic States

\begin{tabular}{|c|c|c|c|c|c|}
\hline Wind farm & $\begin{array}{l}\text { Installed power of } \\
\text { wind farm, MW }\end{array}$ & $\begin{array}{l}\text { Number of wind } \\
\text { turbines }\end{array}$ & Rotor diameter, $\mathrm{m}$ & Hub height, m & Capacity factor \\
\hline \multicolumn{6}{|c|}{ LITHUANIA } \\
\hline Akmenèliai & 6 & 3 & 82 & 98 & 0.25 \\
\hline Benaičiai & 34 & 17 & 82 & 98 & 0.26 \\
\hline Kreivėnai & 20 & 10 & 82 & 78 & 0.24 \\
\hline Kreivènai II & 10 & 5 & 82 & 98 & 0.27 \\
\hline Kreivènai III & 15 & 7 & 82 & 108 & 0.25 \\
\hline Laukžemè & 16 & 6 & 100 & 100 & 0.24 \\
\hline Liepynè & 9.13 & 6 & 82 & 78 & 0.27 \\
\hline Mockiai & 12 & 6 & 82 & 108 & 0.3 \\
\hline Sūdènai & 14 & 7 & 82 & 78 & 0.22 \\
\hline Vydmantai & 30 & 15 & 70 & 85 & 0.21 \\
\hline Seirijai & 6 & 3 & 82 & 78 & 0.18 \\
\hline Šilalè & 13.8 & 6 & 101 & 80 & 0.31 \\
\hline Pakertai & 6 & 3 & 82 & 98 & 0.25 \\
\hline Didšiliai & 21.6 & 10 & 82 & 108 & 0.22 \\
\hline Čiūteliai & 39.1 & 17 & 82 & 108 & 0.28 \\
\hline Kabaldikiai & 45 & 19 & 117 & 120 & \\
\hline
\end{tabular}

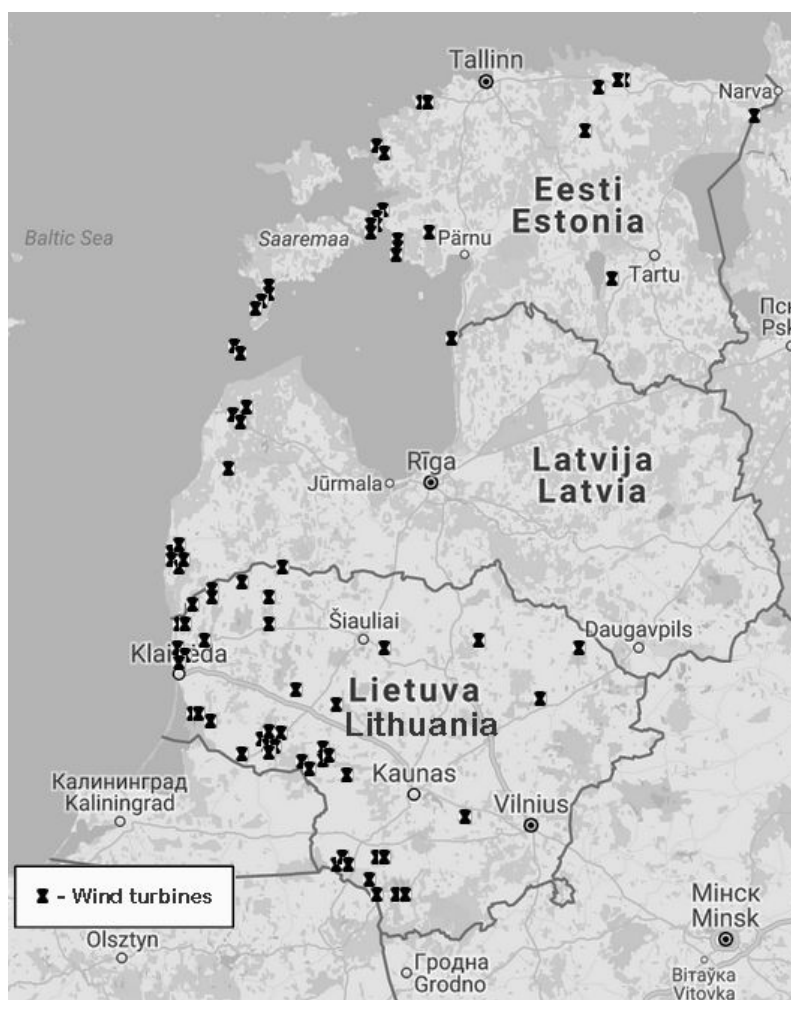

Table 1. Parameters of wind farms in the Baltic States 


\begin{tabular}{|c|c|c|c|c|c|}
\hline Wind farm & $\begin{array}{l}\text { Installed power of } \\
\text { wind farm, MW }\end{array}$ & $\begin{array}{l}\text { Number of wind } \\
\text { turbines }\end{array}$ & Rotor diameter, $\mathrm{m}$ & Hub height, $m$ & Capacity factor \\
\hline Geišiai & 24 & 8 & 117 & 120 & 0.33 \\
\hline Strepeikiai & 73.5 & 30 & 101 & 97 & 0.22 \\
\hline Šilutė & 60 & 24 & 120 & 110 & \\
\hline Kunigiškiai & 7.5 & 3 & 120 & 120 & \\
\hline \multicolumn{6}{|c|}{ ESTONIA } \\
\hline Aulepa & 48 & 16 & 100 & 100 & \\
\hline Esivere & 12 & 4 & & & 0.23 \\
\hline Esivere & 8 & 4 & 71 & 85 & \\
\hline Pakri & 18 & 8 & 90 & 80 & 0.28 \\
\hline Tooma & 16 & 8 & & & 0.25 \\
\hline Vanakula & 9 & 3 & 100 & 90 & 0.17 \\
\hline Viru-Nigula & 24 & 8 & 100 & 90 & 0.22 \\
\hline Virtsu II & 6.9 & 3 & 71 & 85 & 0.23 \\
\hline Nasva & 1,6 & 2 & & & \\
\hline Läätsa & 3 & 6 & & & \\
\hline Virtsu & 1.8 & 3 & 44 & 63 & \\
\hline Virtsu & 0.8 & 1 & 44 & 63 & 0.29 \\
\hline Virtsu III & 6.9 & 3 & 71 & 85 & 0.24 \\
\hline Nasva & 5.9 & 2 & & & \\
\hline Torgu & 0.66 & 3 & & & \\
\hline Aseriaru & 24 & 8 & 103 & 90 & 0.24 \\
\hline Narva Ashfield & 39.1 & 17 & & & \\
\hline Paldiski & 45 & 18 & 100 & 85 & 0.26 \\
\hline Ojakula & 6.9 & 3 & 82 & 98 & 0.19 \\
\hline Tamba & 6 & 2 & 101 & 99 & \\
\hline Mali & 12 & 2 & & & \\
\hline Sikassare & 1.5 & 3 & & & \\
\hline Aburi & 1.8 & 1 & 80 & & \\
\hline Salme II & 3 & 1 & & & \\
\hline \multicolumn{6}{|c|}{ LATVIA } \\
\hline Ainiži & 1.2 & 1 & 43 & & \\
\hline Arsenal & 0.85 & 1 & 52 & & \\
\hline Baltnorvent & 2 & 2 & 54 & & \\
\hline BK Energia & 2 & 1 & 66 & & \\
\hline Enercom Plus & 2.7 & & & & \\
\hline Impakt & 1 & 1 & 54 & & \\
\hline Liepaja & 2 & 1 & 80 & 80 & \\
\hline Pope & 20.7 & 9 & & & 0.27 \\
\hline Seteri & 0.85 & 1 & 52 & & \\
\hline Veju parks & 19.8 & 33 & 40 & 77 & \\
\hline
\end{tabular}


The annual wind power capacity factor $\left(C_{p}\right)$ was estimated by the following equation (Eq. 4):

$$
C_{p}=\frac{E_{\text {fact }}}{E_{p o t}}
$$

where: $C_{p}$ - power capacity factor; $E_{\text {fact }}$ - generated electricity during the year (GWh); $E_{\text {pot }}$ - potential electricity generation during the year (GWh).

The increment of capacity factor regarding the hub height and the rotor diameter of a wind turbine are presented by the following equations (Eq. 5, Eq. 6):

$$
\Delta_{C p h u b h}=C p_{i}-C p_{i-1}
$$

and

$$
\Delta_{C p \text { rotor } d}=C p_{y}-C p_{y-1}
$$

where: $I=20<\ldots>200 \mathrm{~m} . ; y=20<\ldots>150 \mathrm{~m}$.

\section{Results}

\section{Wind power penetration}

Parameters of power demand and wind power systems in the Baltic States are presented in Table 3. Wind power indicators present power generation, installed capacity and different kinds of wind power penetrations levels. It can be noticed that power consumption variations are very significant in all Baltic States and the yearly minimum demand makes up about $30 \%$ of the maximum power demand. Installed power capacity of wind turbines varies in the range of 68-511 MW (Table 1), and it means that wind power is a significant generating source for Lithuania and Estonia and less important for Latvia.

The analysis of wind capacity penetration levels in the Baltic States revealed how the total installed wind power capacity in a certain region, i.e., the indicator, shows the maximum percentage of peak energy load that can be supplied by wind energy.

According to this, wind capacity penetration in Lithuania and Estonia varied on an increasing range from 16.5 to $22.7 \%$ in the period of $2013-2015$. In Latvia, this ratio was $4.6-5.6 \%$ at the same period.

The wind gross demand penetration indicator shows an average wind power impact on the power system demand. Variations of this indicator were in the range from 1.2 to $9.4 \%$ and are dependent on the year and country.

The maximum share of the wind power indicator related with power balance in a certain region, taking into account the minimum demand, the maximum wind power generated and the exchange with neigh-

\begin{tabular}{|c|c|c|c|c|c|c|c|c|}
\hline \multirow{3}{*}{ Country } & \multirow{2}{*}{\multicolumn{3}{|c|}{$\begin{array}{l}\text { Power demand } \\
\text { Installed power, MW } \\
\text { Power production }\end{array}$}} & \multicolumn{5}{|c|}{ Wind power } \\
\hline & & & & \multicolumn{3}{|c|}{ Penetration levels, \% } & \multirow[b]{2}{*}{ Gross demand } & \multirow[b]{2}{*}{ Maximum share } \\
\hline & TWh/a & Peak, MW & Min, MW & & TWh/a & $\begin{array}{l}\text { Wind } \\
\text { capacity }\end{array}$ & & \\
\hline Estonia 2013 & 7.93 & 1425 & 370 & 280 & 0.55 & 19.6 & 7.0 & 65.7 \\
\hline Estonia 2014 & 7.88 & 1490 & 394 & 303 & 0.58 & 20.3 & 7.4 & 68.2 \\
\hline Estonia 2015 & 7.92 & 1394 & 498 & 303 & 0.74 & 21.7 & 9.4 & 55.1 \\
\hline Latvia 2013 & 7.35 & 1344 & 461 & 62 & 0.09 & 4.6 & 1.2 & 10.2 \\
\hline Latvia 2014 & 7.17 & 1315 & 446 & 68 & 0.09 & 5.2 & 1.3 & 9.9 \\
\hline Latvia 2015 & 7.07 & 1225 & 438 & 68 & 0.10 & 5.6 & 1.5 & 10.0 \\
\hline Lithuania 2013 & 9.73 & 1686 & 656 & 279 & 0.49 & 16.5 & 5.0 & 33.7 \\
\hline Lithuania 2014 & 9.67 & 1654 & 635 & 288 & 0.51 & 17.4 & 5.3 & 34.8 \\
\hline Lithuania 2015 & 9.58 & 1970 & 667 & 436 & 0.58 & 22.1 & 6.1 & 33.3 \\
\hline
\end{tabular}
bouring regions or countries. The maximum share

Table 3. Wind power penetration levels in the Baltic Countries 
penetration was $9.9 \%$ in Latvia and $68.2 \%$ in Estonia. This means that Estonia had a relative small power consumption and a relative huge installed wind power capacity. To compare, the maximum wind shear penetration in Lithuania was $33.3-34.8 \%$ in the period of 2013-2015. To conclude, it should be mentioned that utilisation of wind energy in the Baltic States is quite effective and there is no risk that wind power will exceed power demands.

Wind power generation is closely related to power seasonal wind variations. To compare the wind power capacity factor in the winter season, it was by $8 \%$ higher than annual in 2013-2015. Seasonal indicators of wind power generation in the Baltic States are presented in Table 4.

The average wind power penetration and capacity factor during spring and autumn seasons were the same, i.e., $5 \%$ and $21 \%$, respectively. Besides, the average power consumption was similar during spring and autumn periods (924 MW and $948 \mathrm{MW}$, respectively). Despite the fact that power consumption decreased during the summer period, the wind power penetration was lowest (4\%) as well as the capacity factor (15\%).

Table 4. Seasonal indicators of wind power generation in the Baltic States

\begin{tabular}{|c|c|c|c|}
\hline Parameter & 2013 & 2014 & 2015 \\
\hline \multicolumn{4}{|c|}{ Annual } \\
\hline Average power consumption, MW & 952 & 940 & 935 \\
\hline Average wind power generation, MW & 43 & 45 & 55 \\
\hline Wind power penetration, $\%$ & 4.6 & 4.8 & 5.8 \\
\hline Capacity factor, \% & 21.5 & 19.8 & 23.5 \\
\hline \multicolumn{4}{|c|}{ Winter } \\
\hline Average power consumption, MW & 1078 & 1070 & 1033 \\
\hline Average wind power generation, MW & 55 & 63 & 78 \\
\hline Wind power penetration, \% & 5.3 & 6.0 & 7.7 \\
\hline Capacity factor, \% & 27.3 & 27.8 & 33.4 \\
\hline \multicolumn{4}{|c|}{ Spring } \\
\hline Average power consumption, MW & 957 & 898 & 918 \\
\hline Average wind power generation, MW & 42 & 42 & 55 \\
\hline Wind power penetration, $\%$ & 4.4 & 4.8 & 6.0 \\
\hline Capacity factor, \% & 20.5 & 18.6 & 23.9 \\
\hline \multicolumn{4}{|c|}{ Summer } \\
\hline Average power consumption, MW & 839 & 841 & 834 \\
\hline Average wind power generation, MW & 27 & 32 & 39 \\
\hline Wind power penetration, $\%$ & 3.3 & 3.9 & 4.8 \\
\hline Capacity factor, \% & 13.6 & 14.3 & 16.9 \\
\hline \multicolumn{4}{|c|}{ Autumn } \\
\hline Average power consumption, MW & 935 & 954 & 955 \\
\hline Average wind power generation, MW & 49 & 44 & 47 \\
\hline Wind power penetration, \% & 5.4 & 4.6 & 4.9 \\
\hline Capacity factor, \% & 24.9 & 18.8 & 20.0 \\
\hline
\end{tabular}




\section{Wind power capacity factor}

The wind power plants were installed in Lithuania in different years, from 2012 to 2017. Research shows that the power factor rate $(C p)$ of the wind turbine parks in the Baltic countries is in the range of 0.17 0.31 and the values of each park vary over a period of
4 years within $5 \%$, which shows that wind farms generate almost the same amount of energy each year. This makes it possible to predict energy production for the coming years with sufficient accuracy and provides good opportunities for energy production planning for subsequent periods (Fig. 2).

Fig. 2. Variations of capacity factors

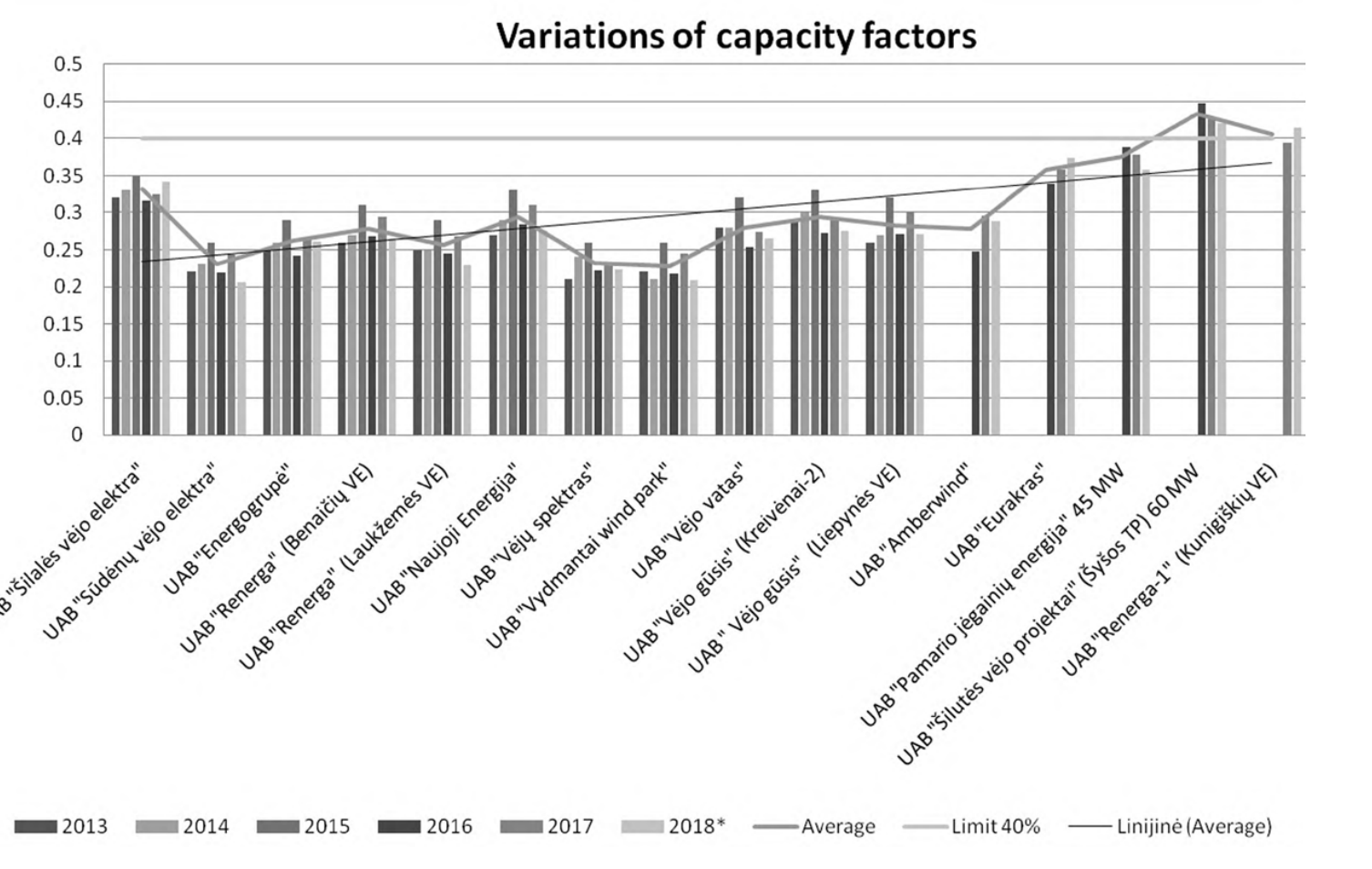

\section{Wind power capacity factor dependence on the hub height and the rotor diameter}

The average size and power of commercial wind turbines has significantly increased in the last decades, as shown by Herbert et al. (2014), and the quantity of wind increases with the increment of height. A tower is used to place the rotor at high altitudes in order to capture more wind energy (Herbert et al., 2014). However, there is a lack of data on how it works in practice and how effectively it depends on the hub height and the diameter of rotor.

The dependence of capacity factors on the hub height, as well as on the rotor diameter, was investigated for wind turbines installed in the Baltic States (Fig. 3 and Fig. 4).
The hub height varied from 24 up to 108 meters, and the diameter of the rotor varied from 23 to 120 meters. From the results of the study, it was noticed that the capacity factor values were both dependent on the hub height and the rotor diameter. Figure 3 demonstrates very different calculated $C p$ values for the same tower hub height. This is obviously related to different wind turbine installation conditions, such as wind, terrain, construction, and others, but the general trend of $C p$ is observable, i.e., an increasing tower hub height increases $\mathrm{Cp}$. The scattering of data was averaged by the approximation curve. It is important to mention that capacity factors rapidly increased in the case of small wind power plants. 
Fig. 3. Capacity factor dependence on the height of the tower; there:

- installed wind turbines, - approximation curve

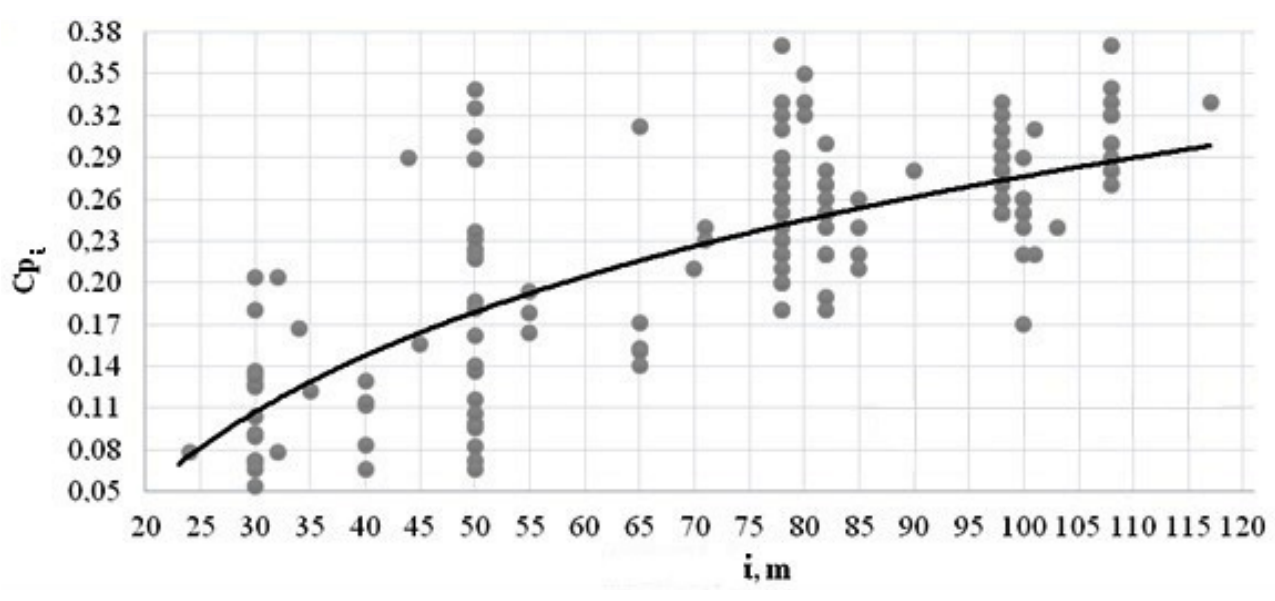

Fig. 4. Capacity factor dependence on the rotor diameter; there - installed wind turbines, - approximation curve

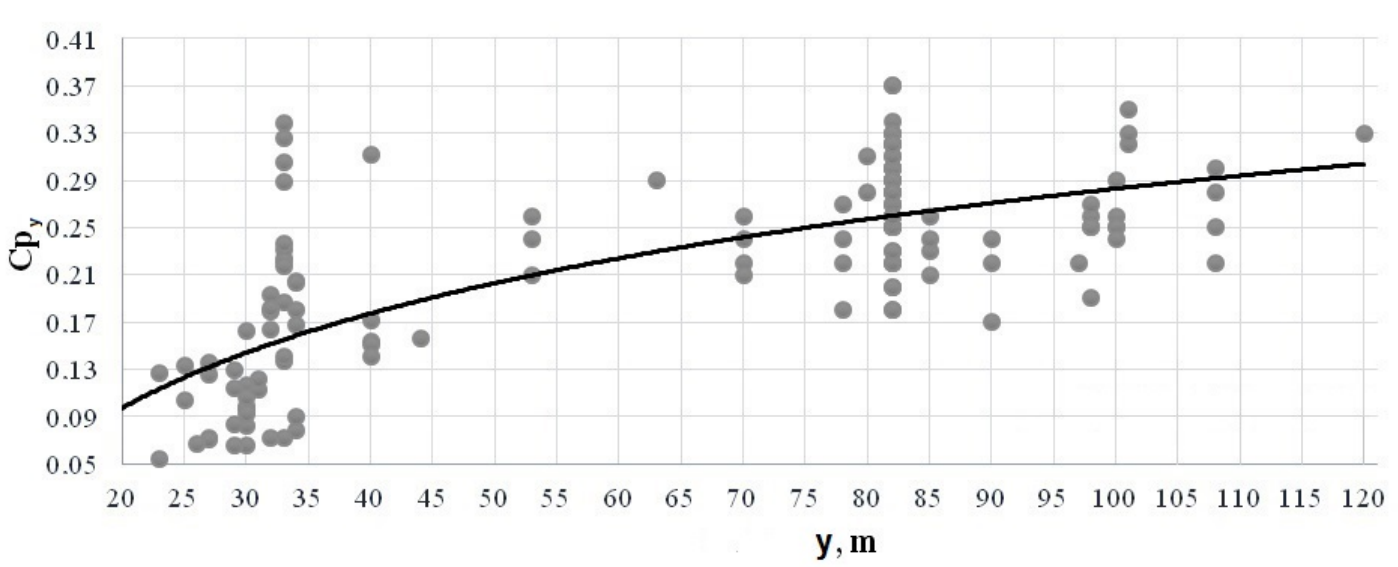

In order to define the increment of capacity factor values by increasing the size of the hub height and the rotor diameter by 1-meter changes, the following mathematical expressions were obtained from Fig. 3 and Fig. 4 as description of approximation curves:

$C p_{i}=0.1404 \ln (i)-0.3703$

and

$C p_{y}=0.1153 \ln (y)-0.248$

were used and calculation results were depicted in Fig. 5 and Fig. 6 accordingly.
As we see from the curves (Fig. 5 and Fig. 6), increasing the hub height and the rotor diameter affects the increment of capacity factor values, but when the hub height and the rotor diameter reach certain values, the increment of capacity factors is lower than at lower values of the rotor and the tower sizes.

It can be seen that the increment of capacity factors dependent on the tower height are slightly bigger than those dependent on the rotor diameter. Besides, considering both sizes (the hub height and the rotor size), a significant increment of capacity factors is in the range of 20-120 m. Further increments of sizes do not have a significant effect on the capacity factor changes. 
Fig. 5. Dependence of the capacity factor increment on the tower height size

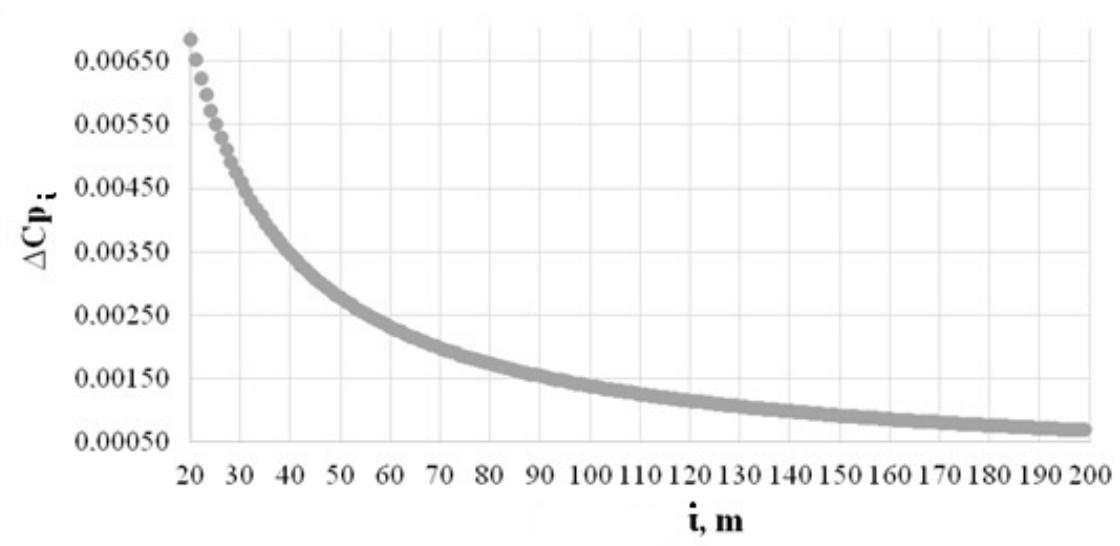

Fig. 6. Dependence of capacity factor increment on the rotor diameter

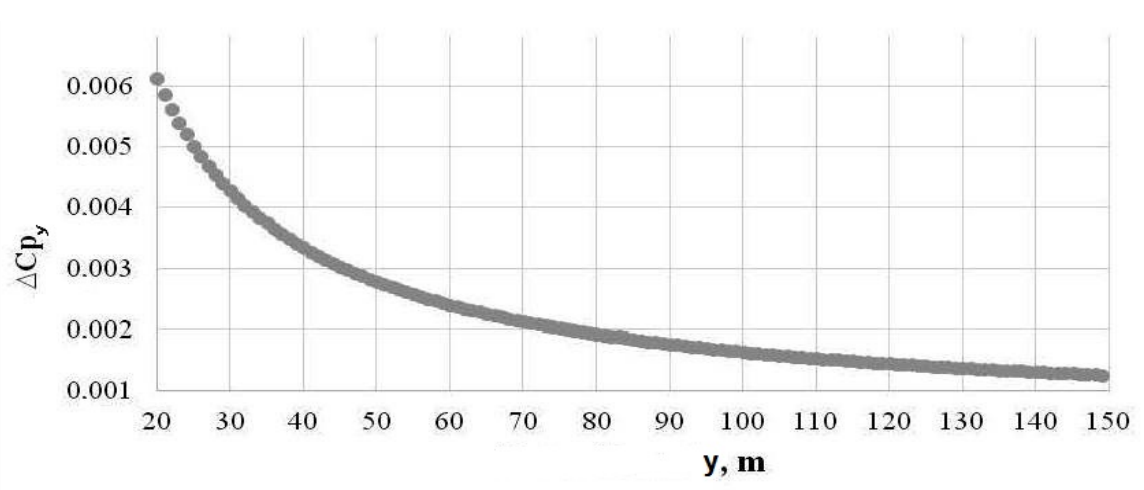

\section{Conclusions}

The analysis of annual power factor rates (CP) of the wind turbine parks in the Baltic States displayed the range of $0.17-0.31$ and the values of each park varying over the period of 4 years within 5 percent. These small variations show that wind farms generate almost the same amount of energy each year, which makes it possible to predict energy production for the coming years with sufficient accuracy.

The wind gross penetration indicator of wind turbine parks varies in the range from 1.2 to $9.4 \%$ and is dependent on the year and the country. The maximum share penetration was 9.9\% in Latvia, 68.2\% in Estonia and 33.3-34.8\% in Lithuania in the period of 2013-2015.
The analysis of the dependence of capacity factors on the hub height and the rotor diameter in the range from 20 to 120 meters of wind turbines installed in the Baltic States indicates that increasing the hub height and the rotor diameter affects the increment of the capacity factor values, but when the hub height and the rotor diameter overstep the $120 \mathrm{~m}$ values, further increment of rotor and tower sizes does not affect substantially the capacity factor dimension.

\{Gurauskiene, 2006, Eco-design methodology for electrical and electronic equipment industry\} 


\section{References}

Benatia, D., Johnstone, N., Haščič, I. (2013) Effectiveness of Policies and Strategies to Increase the Capacity Utilisation of Intermittent Renewable Power Plants. OECD Environment Working Papers, OECD Publishing, Vol. 57, pp. 1-49. ISSN 19970900

Boccard, N.(2009)Capacityfactorofwind power realizedvaluesvs. estimates. Energy Policy, Vol. 37, pp. 2679-2688. ISSN 0301-4215 https://doi.org/10.1016/j.enpol.2009.02.046

Bortolini, M., Gamberi, M., Graziani, A., Manzini, R., Pilati, F. (2014) Performance and viability analysis of small wind turbines in the European Union. Renewable Energy, Vol. 62, pp. 629-639. ISSN 0960-1481. https://doi.org/10.1016/j.renene.2013.08.004

Chang, T. P., Liu, F. J., Ko, H. H. (2014) Comparative analysis on power curve models of wind turbine generator in estimating capacity factor. Energy, Vol. 73, pp. 88-95. ISSN 0360-5442. https://doi.org/10.1016/j.energy.2014.05.091

Dai, J., Liu, D., Wen, L., Long, X. (2016) Research on power coefficient of wind turbines based on SCADA data. Renewable Energy, Vol. 86, pp. 206-215. ISSN 0960-1481. https://doi. org/10.1016/j.renene.2015.08.023

Herbert, J., Iniyan, G.M., Amutha, D. (2014) A review of technical issues on the development of wind farms. Renewable and Sustainable Energy Reviews, Vol. 32, pp. 619-641. ISSN 1364-0321. https://doi.org/10.1016/j.rser.2014.01.055

Hu, J. Harmsen, R., Crijns-Graus, W., Worrell, E., Broek, M. (2018) Identifying barriers to large-scale integration of variable renewable electricity into the electricity market: A literature review of market design. Renewable and Sustainable Energy Reviews, Vol. 81, pp. 2181-2195. ISSN 1364-0321. https://doi. org/10.1016/j.rser.2017.06.028

Mondal, M. A. H., Denich, M. (2010) Assessment of renewable energy resources potential for electricity generation in Bangladesh. Renewable and Sustainable Energy Reviews, Vol. 14, pp. 2401-2413. ISSN 1364-0321. https://doi.org/10.1016/j. rser.2010.05.006

Lacerda, J. S., Van Den Bergh, J. C. J. M. (2016) Mismatch of wind power capacity and generation: causing factors, GHG emissions and potential policy responses. Journal of Cleaner Production, Vol. 128, pp. 178-189. ISSN 0959-6526. https://doi. org/10.1016/j.jclepro.2015.08.005

Li, C., Cao, Y., Shi, H., Wang, J. (2015) Comprehensive review of renewable energy curtailment and avoidance: A specific example in China. Renewable and Sustainable Energy Reviews, Vol. 41, pp. 1067-1079. ISSN 1364-0321. https://doi.org/10.1016/j. rser.2014.09.009

Voumvoulakis, E., Danchev, S., Asimakopoulou, G., Maniatisa, G. (2012) Large scale integration of intermittent renewable energy sources in the Greek power sector. Energy Policy, Vol. 50, pp. 161-173. ISSN 0301-4215. https://doi.org/10.1016/j. enpol.2012.05.056 